\title{
Isoproterenol accelerates apoptosis through the over-expression of the sodium/calcium exchanger in HeLa cells
}

\author{
Sona Hudecova ${ }^{1}$, Lubomira Lencesova ${ }^{1}$, Lucia Csaderova ${ }^{2}$, Jan Sedlak ${ }^{3}$, Viera Bohacova ${ }^{1}$, \\ Marcela Laukova ${ }^{1}$ and Olga Krizanova ${ }^{1}$ \\ ${ }^{1}$ Institute of Molecular Physiology and Genetics, Slovak Academy of Sciences, Bratislava, Slovak Republic \\ ${ }^{2}$ Institute of Virology, Slovak Academy of Sciences, Bratislava, Slovak Republic \\ ${ }^{3}$ Cancer Research Institute, Slovak Academy of Sciences, Bratislava, Slovak Republic
}

\begin{abstract}
Apoptosis induction causes over-expression of the $\mathrm{Na}^{+} / \mathrm{Ca}^{2+}$ exchanger of type 1 (NCX1) in the HeLa cell line. During induction of apoptosis and in the presence of isoproterenol hydrochloride (I; $\beta$-adrenergic agonist), increase in the NCX1 is even more pronounced. Anti-apoptotic Bcl-2 mRNA and protein is markedly reduced during apoptosis and in the presence of $\mathrm{I}$, which causes a rapid increase in the Bax/Bcl-2 ratio. During apoptosis induction by apoptosis inducing kit (A), both with and without I, the active form of caspase-3, which is the executive enzyme in apoptosis, becomes visible on Western blots. Silencing NCX1 resulted in the reversal of the Bax/Bcl-2 ratio, it prevented a decrease in mitochondrial membrane potential compared to the AI group and it decreased the level of AI-induced apoptosis in HeLa cells. Based on the experiments with single apoptotic inducers camptothecin, cycloheximide and dexamethasone, it might be proposed that potentiated apoptotic effect in I-treated cells is due to the inhibition of nuclear topoisomerase. As illustrated in immunofluorescence and Western blot analysis, calnexin increased significantly during induction of the apoptosis in the presence of I. In addition, further decrease in sarco/endoplasmic ATPase 2 (SERCA2), decrease in reticular calcium and mitochondrial membrane potential was observed, which suggests development of the endoplasmic reticulum (ER) stress. Based on these results, we propose that I further enhanced NCX1 expression in apoptotic cells through the development of ER stress.
\end{abstract}

Key words: $\mathrm{Na}^{+} / \mathrm{Ca}^{2+}$ exchanger - Apoptosis - Isoproterenol hydrochloride - Endoplasmic reticulum stress

Abbreviations: A, apoptosis inducing kit; I, isoproterenol; NCX, $\mathrm{Na}^{+} / \mathrm{Ca}^{2+}$ exchanger; PBS, phosphate-buffered saline.

\section{Introduction}

The $\mathrm{Na}^{+} / \mathrm{Ca}^{2+}$ exchanger (NCX) has been shown to play an important role in the induction of apoptosis in many types of cells. Over-expression of the NCX is coupled to endoplasmic reticulum (ER) stress-related apoptosis in insulin-releasing cells (Diaz-Hortha et al. 2002) and also in hypoxia-induced apoptosis in HEK 293 cells (Hudecova

Correspondence to: Olga Krizanova, Institute of Molecular Physiology and Genetics, Slovak Academy of Sciences, Vlárska 5, 83334 Bratislava, Slovak Republic

E-mail: olga.krizanova@savba.sk et al. 2011). However, a major contribution of the NCX to apoptotic cell death was shown in cardiac tissue. Eigel and co-workers (2004) reported that type 1 NCX (NCX1) plays a critical role in the initiation of apoptosis after hypoxia-reoxygenation in ventricular myocytes and that hypoxia-reoxygenation-induced apoptosis is quite sensitive to changes in NCX activity (Eigel et al. 2004). Myocardial tissue undergoing stress is $\beta$-adrenergic receptor ( $\beta$-AR) stimulated and NCX1 is up-regulated at both, the transcriptional and protein levels (Hudecova et al. 2007; Mani et al. 2010; Singh et al. 2011). This up-regulation is a proximate cause in calcium oscillations and sustained intracellular $\mathrm{Ca}^{2+}$ increase, inducing loss of mitochondrial membrane 
potential and subsequent apoptosis (Miyamoto et al. 2005). It was shown, that a cAMP-protein kinase A (PKA) pathway is responsible for the $\beta$-adrenergic stimulation-induced apoptosis in cardiac myocytes (Iwai-Kanai et al. 1999), and thereby this machinery stimulates $\mathrm{Na}^{+} / \mathrm{Ca}^{2+}$ exchange (Barman et al. 2011). It appears that apoptotic pathways are related to the cell type and its physiological status, because activation of this same cAMP pathway almost completely inhibited apoptosis in the pheochromocytoma cell line (PC12, Barman et al. 2011).

Cancer cells are known to be more resistant to apoptotic stimuli, mainly due to deregulation of apoptotic proteins. During early apoptosis, increased permeability of the mitochondrial outer membrane allows the release of pro-apoptotic factors, which promote and amplify the apoptotic cascade. Proteins of the Bcl-2 family are key regulators of this event (Hanahan and Weinberg 2000; Danial 2007). In this family, effector proteins such as Bax are essential for the machinery enabling increased mitochondrial membrane permeability, and anti-apoptotic members such as Bcl-2 inhibit this process by directly binding to the pro-apoptotic effector proteins (Teijido and Dejean 2010). It is well known that a large number of tumour cells have up-regulated anti-apoptotic Bcl-2 protein, which is a part of their enhanced survival strategy, and therefore Bcl-2 is frequently used as tumour marker (Fendri et al. 2011; Papageorgiou et al. 2011). One of the main known functions ascribed to the Bcl-2 family of proteins at the ER is the control of calcium homeostasis. It is presumed that the balance between anti- and pro-apoptotic proteins at the ER has a direct effect on calcium content and release (Rodriguez et al. 2011). Although it has been shown that Bcl-2 over-expressing cells have decreased ER calcium content (Oakes et al. 2006), they simultaneously trigger calcium release to the same extent as Bcl-2-deficient cells which exhibit increased ER calcium content and increased calcium release from the ER following stimulation (Youle and Strasser 2008). Bcl-2 over-expression prevents $\mathrm{Ca}^{2+}$-dependent apoptosis in dystrophic myotubes, and the beneficial effect of $\mathrm{Bcl}-2$ over-expression is most likely mediated by direct $\mathrm{Bcl}$-2-dependent $\mathrm{IP}_{3}$ receptor inhibition (Basset et al. 2006).

$\beta$-adrenergic agonists play a role in carcinogenesis and tumour progression (Entschladen et al. 2005). For example, leukaemia cell apoptosis induced by the $\beta 2$ agonist - beta2Mim - correlated with an increase in calcium influx decreased Bcl-2 protein and mRNA levels, an increase in Bax gene expression and a marked rise in $\mathrm{Bcl}-2 / \mathrm{Bax} \mathrm{mRNA}$ ratios (Mamani-Matsuda et al. 2004). Increased Bcl-2 expression prevented apoptosis in the leukaemia cell, and it has been shown that long-acting $\beta 2$-adrenergic agents promote apoptotic leukaemia cell death through an adrenoreceptor- and cAMP-independent, $\mathrm{Ca}^{2+}$-dependent mechanism (MamaniMatsuda et al. 2004). In contrast, $\beta$-adrenergic antagonists can suppress invasion and proliferation by inhibiting both cAMP/PKA and Ras, which regulate the activation of the MAPK pathway and transcription factors, such as NFkB, AP-1 and CREB, and they also inhibit the expression of target genes (Zhang et al. 2010). Alterations in calcium signalling and/or the expression of calcium pumps and channels are increasingly recognized abilities of some cancer cells. These also include changes in plasma membrane calcium ATPase (PMCA; Roberts-Thomson et al. 2010) or store-operated calcium channels (Wang et al. 2011), but less information is available about the coupling of calcium transport systems with both $\beta$-adrenergic stimulation and apoptosis in cancer cells.

Therefore, the aim of this work is to couple the effects of $\beta$-adrenergic stimulation and the NCX1 during induction and early phase of the apoptosis in a HeLa-stable cell line.

\section{Materials and Methods}

\section{Cells and drugs}

A human cervix carcinoma cell line, HeLa, was grown in 6wells plates in DMEM (Sigma Aldrich, USA) supplemented with $10 \%$ fetal bovine serum (FBS; Sigma Aldrich, USA) and a mixture of streptomycin and penicillin (both from Calbiochem, Merck Biosciences, Darmstadt, Germany) in the humidified atmosphere of $5 \% \mathrm{CO}_{2}$ air at $37^{\circ} \mathrm{C}$. Cells were plated at a density of $1 \times 10^{5}$, and drugs were applied for 24 hours as follows: apoptosis inducer kit (A; Calbiochem, Merck, Darmstadt, Germany) was diluted to 1:1000 as recommended by the producer. A is composed of the following inducers - Actinomycin D, Camptothecin, Cycloheximide, Dexamethasone, and Etoposide. Camptothecin (camp), Cycloheximid (cxi) and Dexamethasone were used also separately in dilution 1:1000. Isoproterenol hydrochloride (I; TOCRIS Bioscience, Ellisville, USA) was used in the final concentration of $10 \mu \mathrm{M}$.

\section{Gene silencing}

HeLa cells were grown in 6-well plates in DMEM with 10\% FBS to $1 \times 10^{5}$. Transfection of siRNAs was performed with DharmaFECT1 (Dharmacon, Thermo Scientific, USA) as described in (Hudecova et al. 2011). ON-TARGET plus siRNAs for human SLC81 (i.e. NCX1; Dharmacon, Thermo Scientific, USA) were applied to the final concentration of 25 pmol per well for 48 hours. The same procedure was performed with Non-Targeting plus siRNAs for scrambled control. Silencing was performed for 48 hours. After the first 24 hours, A and/or I were added to cells and incubated for a further 24 hours. These cells were then harvested and used in further experiments. 
$R N A$ preparation and relative quantification of $m R N A$ levels by reverse transcription followed by polymerase chain reaction (RT-PCR)

The total RNA population was isolated by the TRI Reagent (MRC Ltd., Cincinnati, OH, USA). Briefly, cells were scraped and homogenized by pipette tip in sterile water and TRI Reagent was then added. After 5 minutes, the homogenate was extracted by chloroform. RNAs in the aqueous phase were precipitated by isopropanol, and RNA pellets were washed in $75 \%$ ethanol and stored in $96 \%$ ethanol at $-70^{\circ} \mathrm{C}$. The purity and integrity of the isolated RNAs was checked by GeneQuant Pro spectrophotometer (Biochrom, Buckinghamshire, UK). Reverse transcription was performed using $1.5 \mu \mathrm{g}$ of total RNAs and Ready-To-Go You-Prime First-Strand Beads (GE Healthcare-Life Sciences, USA) with pd(N6) primer. PCR specific for the human type NCX1 (NCX1f 5'-TCCCATCTGT GTGTTCGC-3'; NCX1r 5'TCATCTTGGTCCCTCTCATC-3'; GI: 6453726, annealing - 58 ${ }^{\circ} \mathrm{C}$; Size - $230 \mathrm{bp}$ ), Bcl-2 (Bcl2f 5' $5^{\prime}$ TCCATGTCTTTGGACAACCA-3'; Bcl2r 5'-CTCCACCA GTGTTCCCATCT-3'; GI: 72198188 ; annealing $-56^{\circ} \mathrm{C}$; Size $-183 \mathrm{bp}$ ) and Bax (Baxf 5'-AGAGGATG-ATTGC-CGCCG-3'; Baxr 5'-CAACCACCCTGGTCTTGCATC-3'; GI: 163659848; annealing $-60^{\circ} \mathrm{C}$; Size $-223 \mathrm{bp}$ ) was then performed. Human cyclophilin A (CYCLO; CYCLOf 5'-CGTGCTCTGAGCACTGGG-GAGAAA-3'; CYCLOr 5'-CATGCCTTCTTTCACCTTCCC AAAGAC-3'; GI: 203701; annealing $-60^{\circ} \mathrm{C}$; size $-300 \mathrm{bp}$ ) was used as a housekeeper gene control for semi-quantitative PCR evaluation. All PCR products were analyzed on $2 \%$ agarose gel. The intensity of individual bands was evaluated by measuring the optical density per $\mathrm{mm}^{2}$ and compared relative to the Cyclo. Signals were evaluated by the PCBAS 2.0 software.

\section{Real Time PCR}

Amplification and detection was performed by the ABI Prism 7900HT Sequence detection system (Applied Biosystems Inc., Foster City, CA, USA) with $10 \%$ of the reverse transcription product, $125 \mathrm{nM}$ primers and SYBR Green Master Mix with ROX reference dye (Fermentas, Germany). The reaction was completed in a final volume of $20 \mu \mathrm{l}$ in 96well plates, which were centrifuged to remove air bubbles. Each sample was determined in duplicate, with one "no template" control. Cycles consisted of the initial denaturation step at $95^{\circ} \mathrm{C}$ for $10 \mathrm{~min}$ and initial activation for $2 \mathrm{~min}$ at $50^{\circ} \mathrm{C}$. Each cycle included incubation for $15 \mathrm{~s}$ at $95^{\circ} \mathrm{C}, 30 \mathrm{~s}$ at $56-60^{\circ} \mathrm{C}$ and $30 \mathrm{~s}$ at $72^{\circ} \mathrm{C}$. A routine melting curve analysis was performed following PCR completion to exclude nonspecific products. This was achieved by high resolution data collection during incremental temperature increases from 60 to $95^{\circ} \mathrm{C}$. Data was analyzed by SDS software version 2.3
(Applied Biosystems Inc., Foster City, CA, USA). The copy number of the target genes was normalized to cyclophilin, as an unaffected endogenous reference.

\section{Western blot analysis}

Cells were scraped and pelleted at $1000 \times g$ for $5 \mathrm{~min}$. The pellet was then re-suspended in $10 \mathrm{mM}$ Tris- $\mathrm{HCl}, \mathrm{pH} 7.5$, $1 \mathrm{mM}$ phenylmethyl sulfonylfluoride (PMSF, Serva, Heidelberg, Germany), protease inhibitor cocktail tablets (complete EDTA-free, Roche Diagnostics, Mannheim, Germany) and subjected to centrifugation for $10 \mathrm{~min}$ at $3000 \times g$ and $4^{\circ} \mathrm{C}$ to remove cell debris. Proteins in the supernatant became soluble following incubation for $15 \mathrm{~min}$ at $4^{\circ} \mathrm{C}$ with 3 - [(3cholamidopropyl) dimethyl-ammonio] 1-propanesulfonate (CHAPS; Sigma, St. Louis, MO, USA) added to the final concentration of $50 \mathrm{mM}$. The protein concentration of lysate was determined by the Lowry method (Lowry et al. 1951). Ten to fifty micrograms of protein extract from each sample was separated by electrophoresis on $10-15 \%$ SDS - polyacrylamide gel, and proteins were transferred to the Hybond-P membrane using semi-dry blotting (Owl Inc., Portsmouth, NH). Membranes were blocked in 5\% non-fat dry milk in Tris-buffered saline with Tween-20 (TBS-T), overnight at $4^{\circ} \mathrm{C}$ and then incubated for $1 \mathrm{~h}$ with the appropriate primary antibody. Following washing, the membranes were incubated with secondary antibodies to mouse or rabbit IgG conjugated to horseradish peroxidase, for $1 \mathrm{~h}$ at room temperature. An enhanced chemiluminiscence detection system (ECL Plus, Amersham Biosciences, UK) was used to detect bound antibody. The glyceraldehyde-3-phosphate dehydrogenase (GAPDH) signal from each sample was used as a housekeeper and control protein for quantification. The optical density of individual bands was measured by the Kodak Image station 440 device and quantified using PCBAS 2.0 software.

Antibodies raised against the following proteins were used: Mouse monoclonal antibody to NCX1 (R3F1; Swant, Bellinzona, Switzerland) detects a 116 and $70 \mathrm{kDa}$ protein. This is monoclonal antibody against the canine NCX that recognizes two neighboring but non-overlapping sequences of the hydrophilic region of the exchanger, connecting the putative transmembrane segments 5 and 6 . Thus, two upper bands are splice variants of $116 / 112 \mathrm{kDa}$. For the bar diagram, both bands were evaluated. For caspase- 3 staining, a rabbit anti-caspase-3 polyclonal antibody was used (Calbiochem, Darmstadt, Germany) which recognizes $32 \mathrm{kDa}$ of latent form and $20 \mathrm{kDa}$ of active form of caspase3. Anti-SERCA2 mouse monoclonal antibody (Affinity Bioreagents, USA) binds to the $110 \mathrm{kDa}$ protein. Rabbit polyclonal antibody to calnexin (Abcam, Cambridge, UK) recognizes approximately $90 \mathrm{kDa}$ protein. For Bax protein, mouse monoclonal antibody raised against amino acids 
1-171 of Bax of mouse origin (Santa Cruz Biotechnology, Inc.) was used. This antibody recognized $23 \mathrm{kDa}$ protein. Rabbit polyclonal antibody to Bcl-2 (Abcam, Cambridge, $\mathrm{UK}$ ) detects a band at $26 \mathrm{kDa}$, while the mouse monoclonal antibody to GAPDH (Abcam, Cambridge, UK) binds to the $36 \mathrm{kDa}$ subunit.

\section{Detection of apoptosis with Annexin V-Fluos}

HeLa cells were trypsinized, washed with phosphate-buffered saline $(\mathrm{PBS})$ and pelleted at $1000 \times g$ for $5 \mathrm{~min}$. A cell pellet from each well was re-suspended in $100 \mu \mathrm{l}$ of Annexin V-Fluos (Roche Diagnostics, Mannheim, Germany) labelling solution and incubated at room temperature for $20 \mathrm{~min}$ in the dark. The labelling solution included incubation buffer with 10mM HEPES/NaOH pH 7.4, $140 \mathrm{mM}$ $\mathrm{NaCl}$ and $5 \mathrm{mM} \mathrm{CaCl}_{2}, 2 \mu \mathrm{l}$ of Annexin V-Fluos and $0.02 \mu \mathrm{g}$ propidium iodide (Roche Diagnostics, USA). Following this incubation, the reaction was terminated by adding $300 \mu \mathrm{l}$ ice-cold PBS, and products were measured in 96-well plates by the Accuri C6 flow cytometer (BD Accuri Cytometers Ann Arbor, MI, USA).

\section{Cytofluorometric analysis of the mitochondrial membrane potential}

Analysis of mitochondrial membrane potential via $\psi_{\mathrm{m}}$ was performed as described in Jakubikova et al. (2005). Briefly; cells were collected by centrifugation at $1000 \times g$ for $5 \mathrm{~min}$ and washed twice with cold PBS. Incubation was performed in $200 \mu \mathrm{l}$ of $\mathrm{PBS} / 0.2 \%$ bovine serum albumine (BSA) containing $4 \mu \mathrm{M}$ fluorescent dye 5,5',6,6'-tetrachloro-1,1,3,3'tetraethylben-zimidazolyl-carbocyanine iodide (JC-1) and 7 -aminoactinomycin D (7-AAD; $5 \mathrm{ng} / \mu \mathrm{l}$; both from Invitrogen, Life Technologies, USA) for $30 \mathrm{~min}$ at $37^{\circ} \mathrm{C}$ in the dark. 7-AAD was used to exclude population of necrotic cells. Cell data was acquired using the Epics Altra (Beckman Coulter) flow cytometer equipped with $488 \mathrm{~nm}$ excitation laser and fluorescence emission of JC- 1 green, JC-1 red; and 7-AAD was measured using a band pass filter set at 525, 575, and $675 \mathrm{~nm}$, respectively. Forward and side light-scattering characteristics were used to exclude cell debris from the analysis. For each analysis, $1 \times 10^{4}$ cells were acquired, and the ratio of JC-1 red/JC-1 green fluorescence of viable cells (7-AAD negative) was used to calculate the decrease in $\psi_{\mathrm{m}}$. Data was analyzed by FCS4 software (De Novo Software, Los Angeles, CA, USA).

\section{Immunofluorescence}

Immunofluorescence was performed using the procedure described in Hudecova et al. (2011). Briefly; HeLa cells were plated on poly-L-lysine (Sigma-Aldrich, St. Louis,
MD, USA) coated $(10 \mathrm{mg} / \mathrm{ml})$ coverslips in Sarstedt 24 well plates in $1 \mathrm{ml}$ of DMEM medium, with $10 \%$ of fetal bovine serum and a mixture of streptomycin and penicillin (both from Calbiochem, Merck Biosciences, Darmstadt, Germany). Cells were incubated in the humidified atmosphere of $5 \% \mathrm{CO}_{2}$ air at $37^{\circ} \mathrm{C}$. Following these treatment procedures, the cells were fixed in ice-cold methanol. Non-specific binding was blocked by incubation with PBS containing 1\% BSA (Merck Biosciences, Darmstadt, Germany) for $30 \mathrm{~min}$ at $37^{\circ} \mathrm{C}$. The cells were then incubated with primary antibodies diluted to 1:1000 for $60 \mathrm{~min}$ at $37^{\circ} \mathrm{C}$. We used primary mouse monoclonal antibody to NCX1 and rabbit polyclonal antibody to calnexin (Abcam, Cambridge, UK). The coverslips were washed in PBS and incubated with Alexa Fluor 594 Goat Anti Mouse IgG $(\mathrm{H}+\mathrm{L})$ secondary antibody (Life Technologies) and CFTM488 Goat Anti-Rabbit IgG $(\mathrm{H}+\mathrm{L})$ (Biotium, Hayward, CA, USA) secondary antibody for $60 \mathrm{~min}$. at $37^{\circ} \mathrm{C}$. Finally, the cells were mounted on slides in a mounting medium with Citifluor (Agar Scientific, Essex, UK), and analyzed by LSM 510 Meta microscope (Zeiss) with EC plan-Neofluar 40x objective. All images were produced by identical camera and microscope setup.

\section{NCX activity in HeLa cells}

NCX transport was measured as described in Hudecova et al. (2011). Briefly: plated cells were washed for $3 \mathrm{~min}$ with hypotonic cell solution $(0.1 \mathrm{mM} \mathrm{MgCl} 2$ and $3 \mathrm{mM} \mathrm{HEPES}$, $\mathrm{pH}$ 7.4). An isotonic cell solution was then added, with Fluo$3 \mathrm{AM}$ (Invitrogen, USA) and calcium ( $1 \mathrm{mM} \mathrm{MgCl}_{2}, 10 \mathrm{mM}$ HEPES ( $\mathrm{pH} 7.4$ ), $10 \mathrm{mM}$ glucose, $\mathrm{CaCl}_{2}$ to a final concentration of $500 \mu \mathrm{M}$, Fluo-3 AM to a final concentration of $8 \mu \mathrm{M}$ and pluronic acid to $0.04 \%$ ). After 20 min loading in the dark at room temperature, cells were washed with isotonic cell solution and a solution of $5 \mathrm{mM} \mathrm{KCl}$ or $140 \mathrm{mM} \mathrm{NaCl}$ was added. The fluorescence signal was measured by the fluorescence reader BioTec at $37^{\circ} \mathrm{C}$. Excitation was measured at $485 \mathrm{~nm}$ and emission at $528 \mathrm{~nm}$. Calcium transport was calculated from the difference in the fluorescent signal for the $\mathrm{KCl}$ and $\mathrm{NaCl}$ solutions. The control for the fluorescent signal was achieved by adding $10 \%$ SDS and $50 \mathrm{mM}$ EGTA ( $\mathrm{pH}$ 7.4) following the measurements. Calcium transport was expressed in arbitrary fluorescent units.

\section{$\left[\mathrm{Ca}^{2+}\right]$-free measurement in reticular fraction with fluorescent dye Rhod-5N}

Cells were scraped from wells, sedimented and washed with $1 \times$ PBS solution. Gentle lysis was performed with $100 \mu \mathrm{l}$ of cell lysis buffer from the kit for cytoplasmic and nuclear protein isolation (ProteoJetTM, Fermentas, Germany) and dithiothreitol to a final concentration of $1 \mathrm{mM}$. Postmi- 
tochondrial fractions with endoplasmic cisternae were isolated as described in Pacak et al. (2012). Pellets from the post-mitochondrial fraction were homogenized in nuclear lysis buffer from ProteoJet ${ }^{\mathrm{TM}}$ kit and pipetted to wells in a 24-well plate. Rhod-5N fluorescent dye (Invitrogen Ltd., Paisley, UK) was added to each sample to a final concentration of $20 \mu \mathrm{M}$. Measurements were performed by the BioTek fluorescent reader (excitation $551 \mathrm{~nm} /$ emission $576 \mathrm{~nm}$ ). After measuring fluorescence (F), the signal was saturated by adding EGTA solution ( $\mathrm{pH}$ 7.0) to a final concentration of $2.5 \mathrm{mM}\left(\mathrm{F}_{\min }\right)$. The $\mathrm{F}_{\max }$ value was measured by adding $100 \mathrm{mM} \mathrm{CaCl}_{2}$ to a final concentration of $0.5 \mathrm{mM}$. The final values of $\left[\mathrm{Ca}^{2+}\right]$-free were calculated according to the formula: $\left[\mathrm{Ca}^{2+}\right]_{\text {free }}=\mathrm{K}_{\mathrm{d}}\left[\left(\mathrm{F}_{\max }-\mathrm{F}\right) /\left(\mathrm{F}-\mathrm{F}_{\min }\right)\right]$, where $\mathrm{K}_{\mathrm{d}}$ for Rhod- $5 \mathrm{~N}$ is $320 \mu \mathrm{M}$. Results were expressed as micromoles of calcium per micrograms of protein.

\section{Statistical analysis}

Each value resulted from an average of 24-30 wells in at least 4 independent cultivations of HeLa cells. Results are presented as mean \pm S.E.M. Statistical differences between the groups were determined by ANOVA. Statistical significance of $p<0.05$ was considered as significant for ${ }^{*}$ and ${ }^{* *} p<0.01,{ }^{* *} p<0.001$ compared to controls. Statistical significance of $+p<0.05,++p<0.01$ and $+++p<0.0001$ was considered to be significant compared to A-treated group. An adjusted t-test with $p$ values corrected by the Bonferroni method was used for multiple comparisons (Instat, GraphPad Software).

\section{Results}

Gene expression of the NCX1 was increased approximately 3 -times in HeLa cells after 24 hours treatment with apoptosis inducer kit (A; Fig. 1a) and approximately 7-times in the cells treated with combination of A and I (AI; Fig. 1a). Subsequently, this increase was followed by an elevation of protein signal of the NCX1 and also by the NCX transport activity (Fig. 1b, c). Protein levels of the ER stress marker - calnexin - revealed rapid increase in group treated with A and I simultaneously (AI; Fig. 2c). SERCA2 was decreased after 24 hours of treatment with A and also in the cells, where combination of A and I was applied (AI; Fig. 2b). Combination of A and I also caused significant decrease in the reticular calcium content (Fig. 2a). No significant change was observed in groups treated with I or A, which supports the proposal about development of the ER stress in cells treated with their combination (AI), whereas apoptosis inducer kit is acting through other pathways. In order to see if the ER stress induced by combination of the A and I can result in apoptosis, we amplified mRNA signals by RT-PCR method (Fig. 3a) and also determined proteins by Western blot analysis (Fig. 3b), for pro-apoptotic marker Bax and anti-apoptotic marker Bcl-2. We have shown that in the cells treated with $\mathrm{A}$, a significant increase of Bax signal was present and complementary to that, levels of Bcl-2 were decreased (Fig. 3a,b ). Ratio of these two components of apoptotic pathway shows not only development of apoptosis in the cells treated with A, but also massive increase in the apoptotic signal in the HeLa a

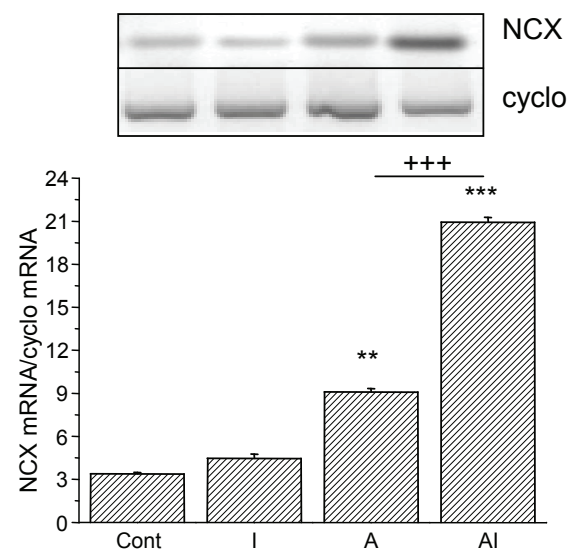

b

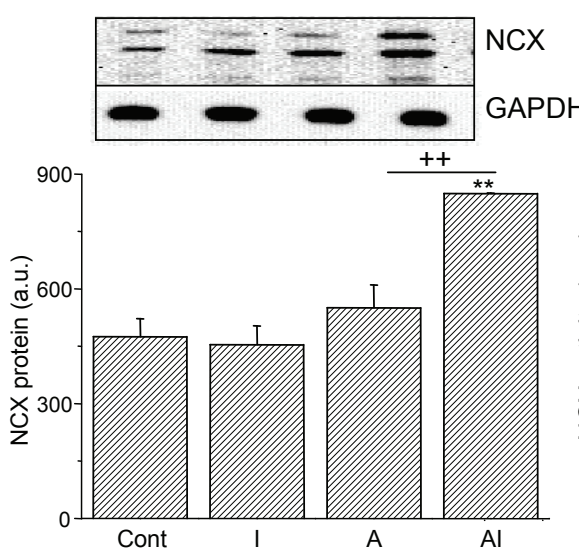

C

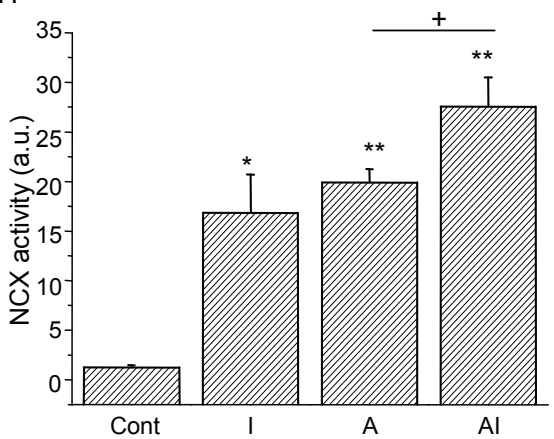

Figure 1. Treatment of HeLa cells with apoptosis inducing kit (A) and isoproterenol (I) enhances expression of the NCX1. Elevation in mRNA signal for the NCX1 (a) occurs in cells treated 24 hours with A and in cells treated with a combination of A and I (AI). Western blot analysis of the NCX1 protein shows same effect (b). Over-expression of the NCX1 is (at least partially) associated with enhanced $\mathrm{Na}^{+} / \mathrm{Ca}^{2+}$ transport activity $(\mathbf{c})$. Each column represents an average of at least 5 independent cultivations. Significance compared to control group (Cont): ${ }^{\star} p<0.05,{ }^{* *} p<0.01,{ }^{* *} p<0.001$ and significance between A and AI: $+p<0.05,++p<0.01,+++p<0.001$. 
a

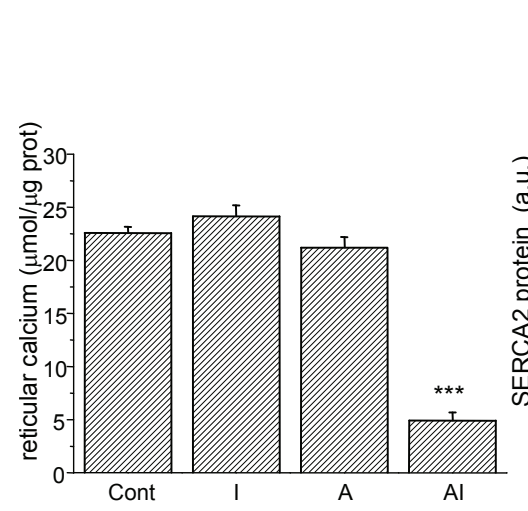

b

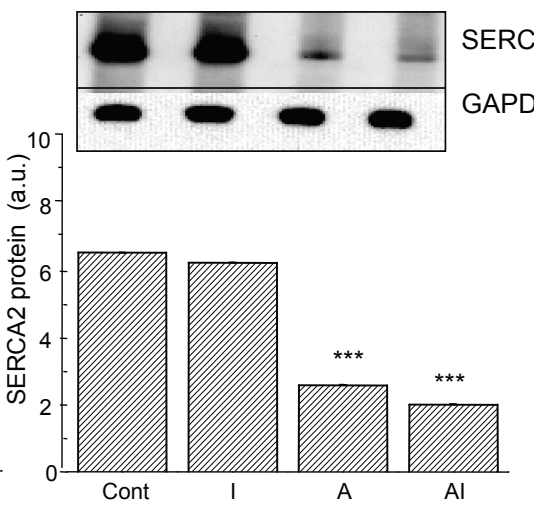

C
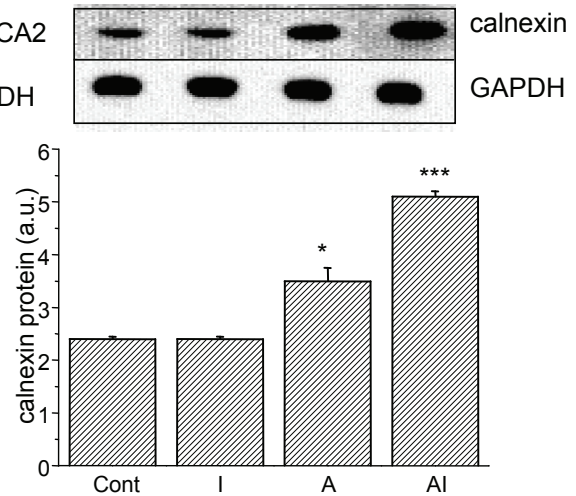

Figure 2. Treatment of HeLa cells with apoptosis inducing kit (A) and isoproterenol (I) decreases reticular calcium (a) and SERCA2 protein (b), while increasing expression of the calnexin (c). Western blot analysis reveals down-regulation of the sarco/endoplasmic reticulum $\mathrm{Ca}^{2+}{ }_{-}$ ATPase2 (SERCA2), simultaneously with a calcium depletion of the ER in cells treated with combination of the A and I. Protein levels of the ER chaperone calnexin are elevated in the group of A-treated cells, but a pronounced effect is seen in the cells treated with the AI combination. Each column represents an average of at least 5 independent cultivations.Significance compared to control group (Cont): ${ }^{\star} p<0.05,{ }^{\star *} p<0.01$, ${ }^{* * *} p<0.001$.
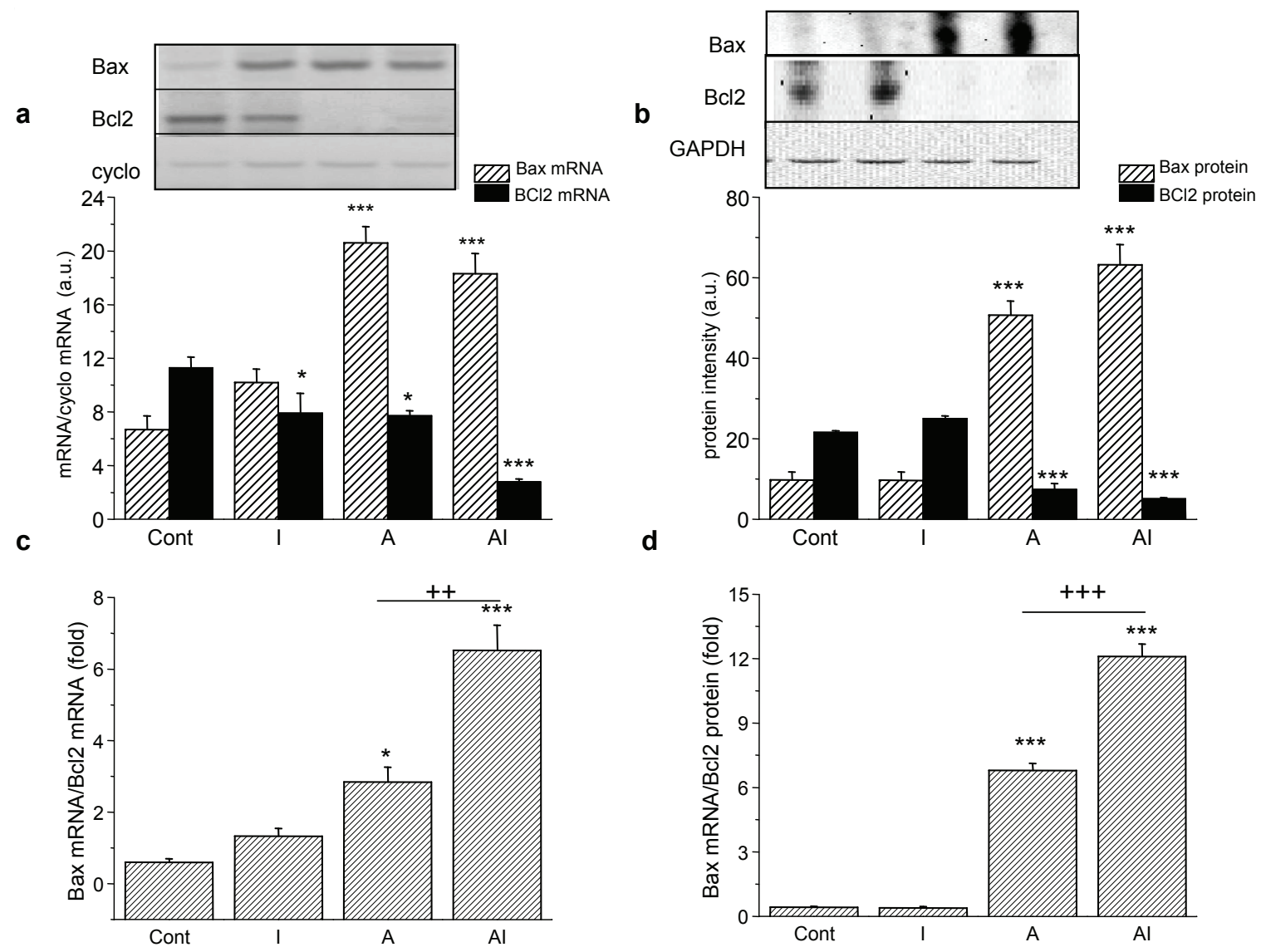

Figure 3. Determination of Bax, Bcl-2 and their ratio in HeLa cells after A and I treatment. The mRNA (a) and also protein (b) signal for pro-apoptotic protein Bax was significantly elevated in cells treated with the A and AI combination, whereas the anti-apoptotic Bcl-2 signal is significantly decreased on both mRNA and protein levels. The Bax/Bcl-2 ratio (c, d) may indicate an enhanced apoptotic process. Significance compared to the control group (Cont): ${ }^{*} p<0.05,{ }^{* * *} p<0.001$, and to the A-treated group: $+p<0.05,++p<0.01,+++p<0.001$. 
cells treated with combination of the A and isoproterenol (Fig. 3 c,d). Bax/Bcl2 ratio was similar when calculated from mRNA or protein levels.

The possible role of the NCX1 in this pathway was proven by gene silencing of the NCX1 mRNA. NCX1 mRNA was silenced to app. $20 \%$ of the original value (Fig. $4 \mathrm{a})$, as determined by the real-time PCR. When combination of the A and I was applied to cells with silenced NCX1, ratio of the Bax/Bcl-2 decreased to control levels (Fig. 4b). In cells treated with scrambled control siRNA and subsequently with combination of $A$ and I, this effect has not been observed. In order to prove the direct effect of NCX1 silencing on apoptosis, appearance of active caspase-3 (Fig. 5a) binding of Annexin V-Fluos (Fig. 5b) and also drop in mitochondrial membrane potential (Fig. $5 c$ ) was measured. Activation of caspase-3 plays a central role in the execution-phase of cell apoptosis. Western blot analysis shows that in control cells and cells treated with I, most of the caspase- 3 is in the inactive form, whereas in the cells treated with A and combination of drugs, a band for active form occurs (Fig. 5a). Apoptosis measured by Annexin V-Fluos revealed significant increase in the AI group compared to control and this increase was significantly abolished in AI group with silenced NCX1
(Fig. 5b). An involvement of mitochondria in the mechanisms of apoptosis was determined from a ratio of red fluorescence of JC-1 aggregates and green fluorescence of JC-1 monomers. Aggregation of monomers is directly correlated to mitochondrial membrane potential $\psi_{\mathrm{m}}$ and their breakdown in dying cells results in increase of green fluorescence. In upper part of Fig. 5c, typical result of red/green ratio, indicating depolarization of mitochondrial membranes could be seen for control (Cont), A treated cells without (A) and with isoproterenol (AI). Experiments with $\psi_{\mathrm{m}}$ clearly showed that in the cells treated with A (A) increased percentage of cells with depolarized mitochondrial membrane compared to control cells (A; Fig. 5c) and this increase was potentiated in cells treated with combination of A and isoproterenol (Fig. 5c; AI). Silencing of the NCX1 (AIsil) prevented changes in the mitochondrial membrane potential $\left(\psi_{\mathrm{m}}\right)$, whereas scrambled RNAs had no such pronounced effect (AIscr Fig. 5c).

Since individual apoptotic inducers used in A act on different pathways, we used camptothecin (camp), cycloheximid (cxi) and dexamethasone (dex). After the treatment of these compounds with I we compared NCX1 mRNA levels (Table 1) and apoptosis via Annexin V-Fluos positive cells (Fig. 6). Although all these compounds increased NCX1 a

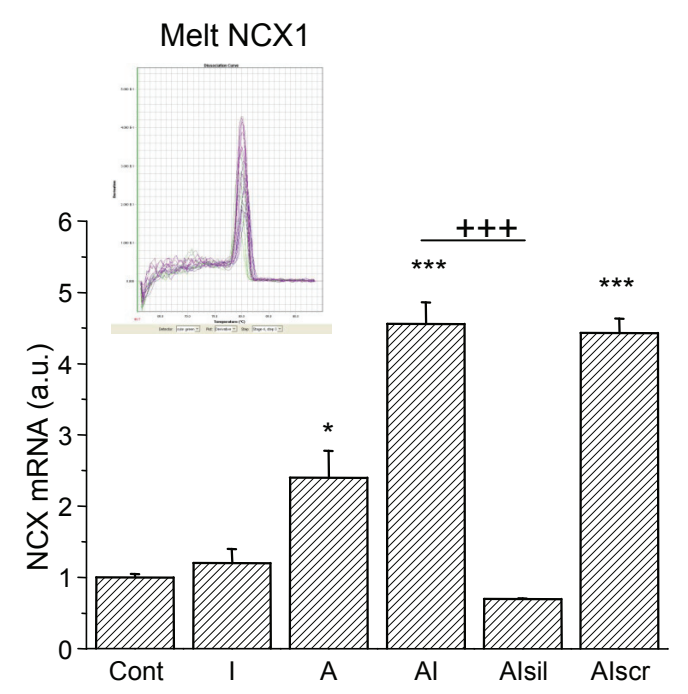

b

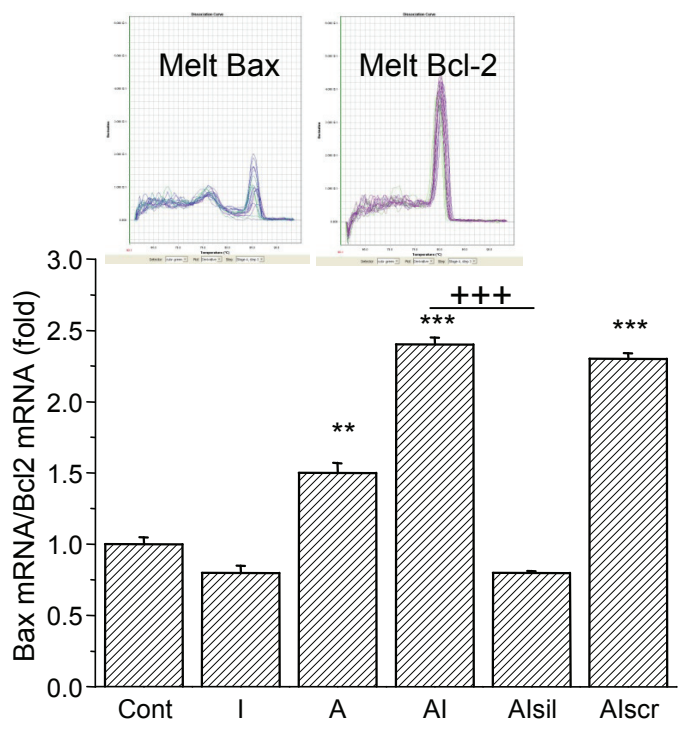

Figure 4. Effect of the NCX1 silencing on the Bax/Bcl-2 ratio in AI combination. To assess whether the increase in AI combination observed in the Bax/Bcl-2 ratio is due to NCX1 up-regulation, we silenced the NCX1 mRNA (AIsil). We observed rapid silencing of the NCX1 by both classical PCR (not shown) and real-time PCR (a). Subsequently, a decrease in Bax/Bcl-2 ratio was observed in the AIsil group, but not in the group where scrambled siRNA (AIscr) was used as a control (b). This proved the involvement of NCX1 up-regulation in the development of apoptosis in the AI group. Each column represents an average of at least five independent cultivations. Significance compared to the control group is ${ }^{\star} p<0.05,{ }^{* *} p<0.01,{ }^{* *} p<0.001$ and significance between AI and AIsil is $+++p<0.001$. 
a

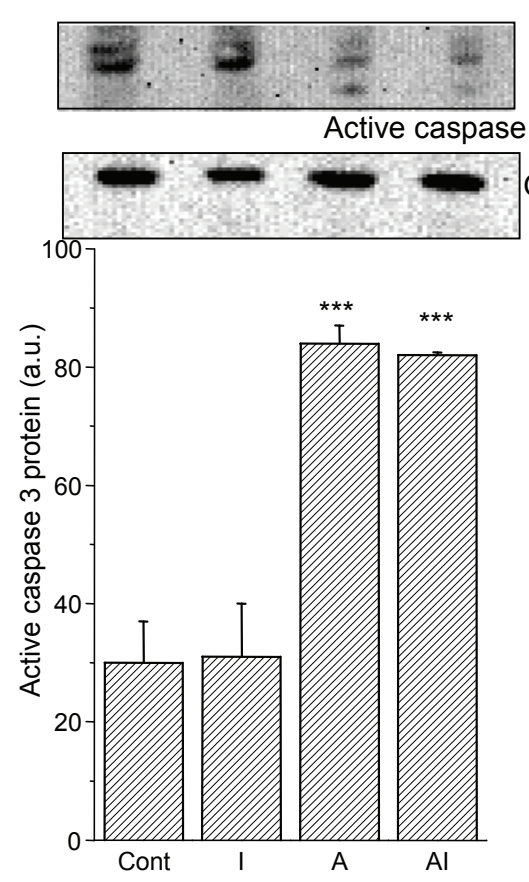

b

\section{$-$}

nopt

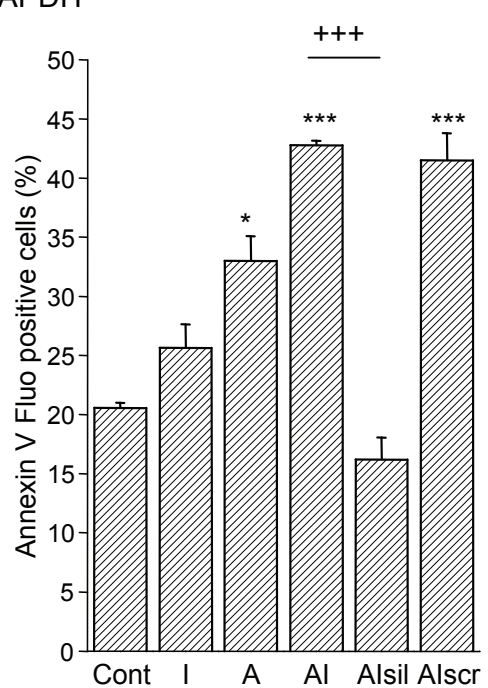

C
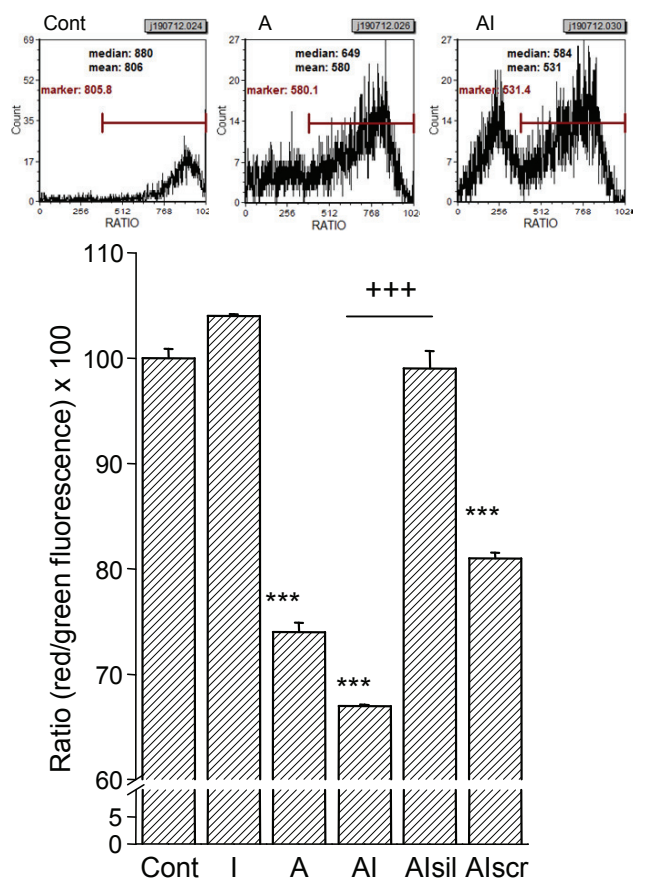

Figure 5. Determination of the Caspase-3 (a), \% of apoptotic cells measured by Annexin V-Fluos (b) and changes in mitochondrial membrane potential (c). Western blot analysis revealed the active form of caspase-3 in cells treated with A and the combination of A and I (AI), while the inactive upper band remained strongest in the group of control cells (Cont) and in cells treated with isoproterenol (I; a - upper part). When the group of cells treated with A and the AI combination (AI) was silenced by the NCX1 siRNA, the band of activated caspase- 3 disappeared, while in the group of AI cells treated with the scrambled siRNA, the active form of Caspase- 3 was detected (not shown). These results correspond with the determination of the apoptotic process by Annexin V-Fluos (b), where apoptosis was significantly reduced in AI cells treated with silenced NCX1. The apoptotic changes induced depolarization in the mitochondrial membranes. The decrease in mitochondrial membrane potential was significantly changed in HeLa cells treated with A (c), and it was further potentiated in cells treated with a combination of A and isoproterenol (AI). Silencing NCX1 prevented changes in $\psi_{\mathrm{m}}$ (AIsil). Cells treated with scrambled RNAs (AIscr) did not show the effect as AIsil, thus highlighting the specific effect of silencing on mitochondrial membrane potential. Significance compared to Cont: ${ }^{*} p<0.05,{ }^{* *} p<0.001$, and the significance compared to the AI group: $+++p<0.001$.

mRNA, no significant difference was observed after dex and dexI groups (Table 1). Thus, for apoptotic measurements we used camp and cxi. Significant difference in the number of

Table 1. NCX1 mRNA/cyclophilin mRNA signal as determined by real-time PCR

\begin{tabular}{lll}
\hline Group & Mean \pm SEM (a.u.) & $n$ \\
\hline Control & $13.32 \pm 1.28$ & 6 \\
Isoproterenol & $12.49 \pm 0.40$ & 6 \\
Apoptosis & $53.40 \pm 3.89$ & 4 \\
Apoptosis/isoproterenol & $147.8 \pm 6.70$ & 5 \\
Cycloheximid & $10.12 \pm 1.11$ & 3 \\
Cycloheximid/isoproterenol & $81.65 \pm 5.84$ & 3 \\
Camptothecin & $78.51 \pm 4.00$ & 3 \\
Camptothecin/isoproterenol & $125.33 \pm 4.30$ & 3 \\
Dexamethasone & $17.22 \pm 0.52$ & 3 \\
Dexamethasone/isoproterenol & $19.45 \pm 0.89$ & 3 \\
\hline
\end{tabular}

apoptotic cells in I-treated group was observed in camp, but not in cxi (Fig. 6).

Calnexin is a chaperone, which retains unfolded or unassembled N-linked glycoproteins in the ER. Therefore, this protein is commonly considered for a marker of ER stress. In order to show NCX1 and calnexin levels in the same cells, we performed double labeling with the NCX1 and calnexin antibodies (Fig. 7). In A-treated cells (A) red signal of the NCX1 became more intensive compared to control, while no green calnexin signal was visible. In the cells treated with the combination of A and I (AI), both signals were pronounced. In cells, where the NCX1 was silenced and cells were treated with combination of the A and I, green calnexin signal disappeared (AIsil; Fig .7). In HeLa cells, where the scrambled siRNA as a negative silencing control was used and cells were treated with combination of the A and I, both red NCX1 signal and green calnexin signal appeared (AIscr; Fig. 7). 

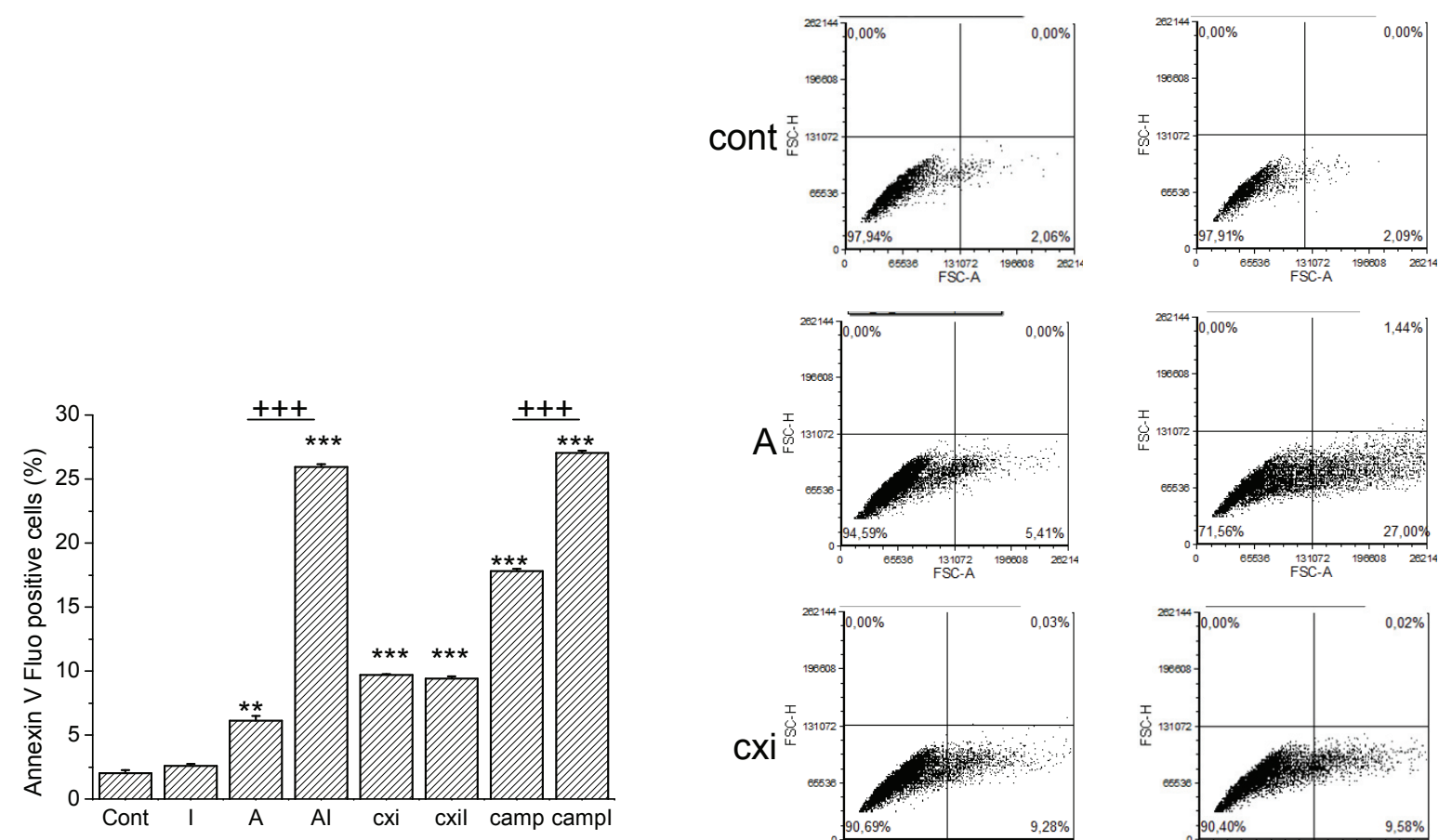

Al
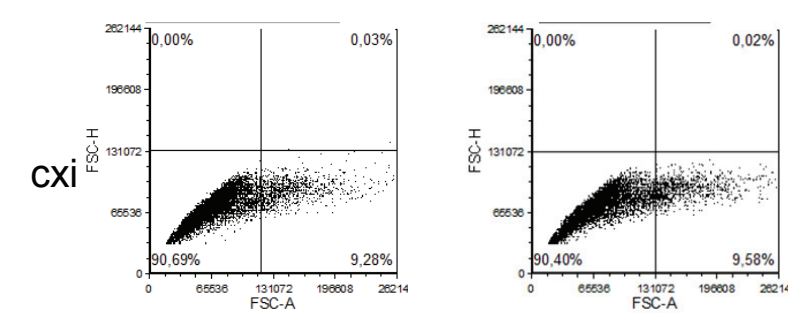

cxil
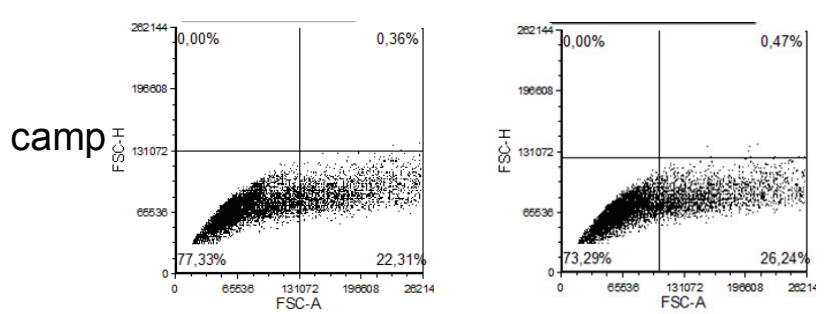

campl

Figure 6. Effect of cycloheximid (cxi), and camptothecin (camp) on the number of apoptotic cells in the presence of isoproterenol (I). On the right side, typical cytometric plot from each group is shown. Results are displayed as mean \pm S.E.M. and each column represents an average of three cultivations. Statistical significance compared to Cont: ${ }^{\star *} p<0.01,{ }^{* *} p<0.001$, and the significance compared to the apoptotic group without I: $+++p<0.001$.

\section{Discussion}

NCX is an important regulator of intracellular calcium homeostasis, described mainly in the cardiac cells (for review see Maier, 2012). In these cells, NCX function is ultimately connected with the catecholamine pathway and thus with signaling through adrenergic receptors (Orchard and Brette 2009). Nevertheless, function of the NCX in other tissues is still under elucidation. In pancreatic beta-cells overexpression of the exchanger increases $\mathrm{Ca}^{2+}$-dependent and $\mathrm{Ca}^{2+}$ independent beta-cell death by apoptosis, a phenomenon resulting from the depletion of $\mathrm{ER} \mathrm{Ca}^{2+}$ stores with subsequent activation of caspase-12 (Herchuelz et al. 2002). Activation of the process of apoptosis might be of a special interest in cancer cells. However, little is known about the regulation and function of the NCX in cancer cells. In this work we have shown that in HeLa cells, induction of apoptosis increased gene expression of the NCX1, which results in the elevation of the NCX1 protein and activity, while I does not affect mRNA and protein levels of this transport system, but increased activity of the NCX. This would point to different regulatory sites of I and apoptosis induction on the NCX. Surprisingly, in the cells treated with A and I, increase in the NCX1 mRNA was much more pronounced compared to A-treated cells only. Mechanism of this increase is not known, nevertheless, experiments with NCX1 silencing in AI-treated cells clearly point to up-regulation of the gene expression.

Cytotoxicity of several compounds might be mediated by induction of the ER stress in various cancer cells (Caba et al. 2012; Chiu et al. 2012; Liu et al. 2012; Zha et al. 2012). Induction of apoptosis through the ER stress is an accepted 


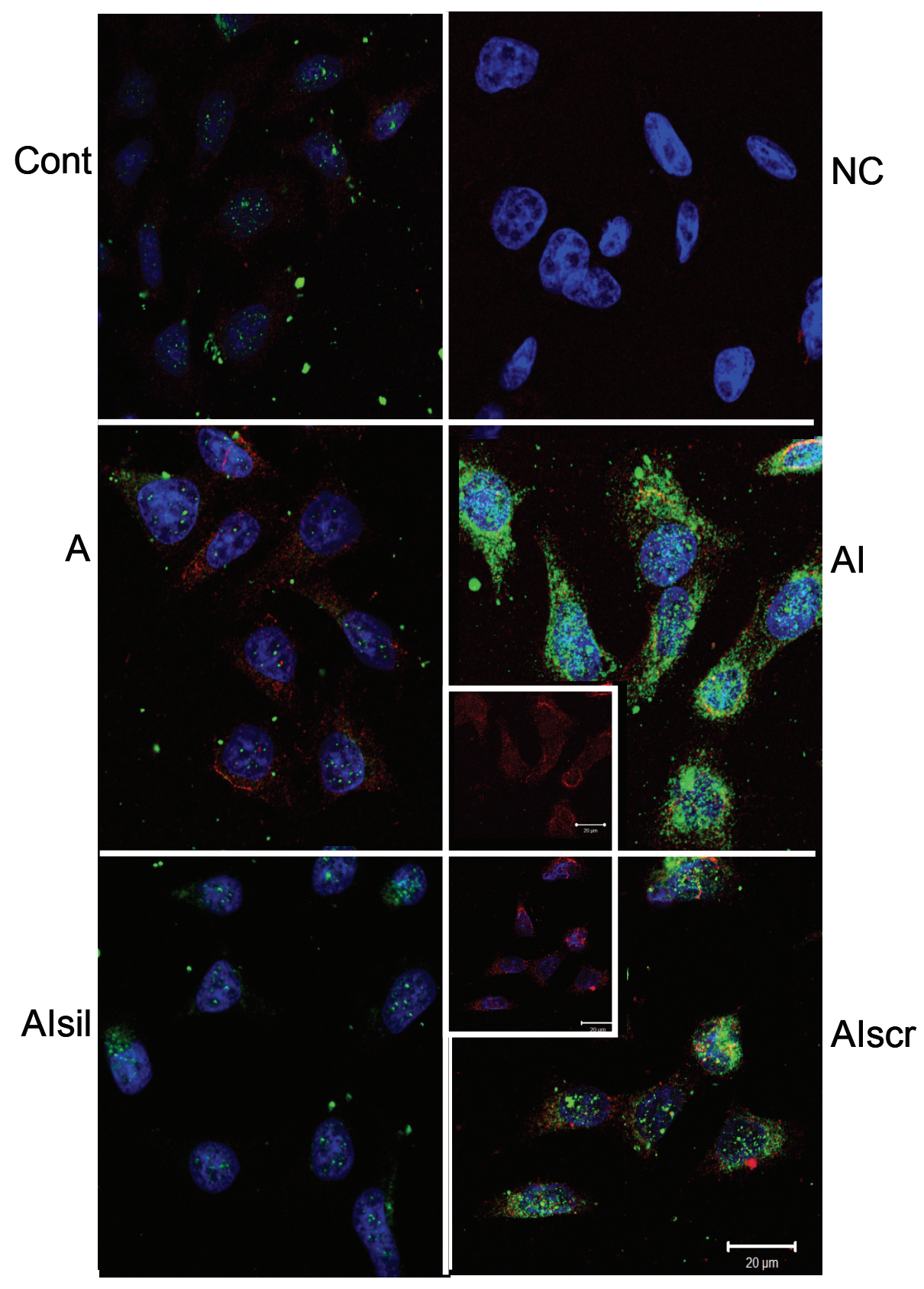

Figure 7. Immunofluorescent staining of the NCX1 (red) and calnexin (green) in HeLa cells. Control cells (Cont) expressed low levels of both NCX1 and calnexin. NC represents negative control without primary antibodies. Treatment with A caused a significant rise in the NCX1 signal, but not in the calnexin one. When cells were treated with both, A and I (AI), a massive increase of calnexin signal beside the NCX1 (small inset, red) is clearly visible. Both signals diminished in the NCX1-silenced group of cells (AIsil), but when scrambled siRNAs (AIscr) were used in these cells, both the NCX1 and calnexin signals exhibited the same intensity as in AI (NCX signal is in the inset). Each bar in the figure (also in insets) represents $20 \mu \mathrm{m}$.

phenomenon (Park et al. 2012). ER is an organelle intimately involved in control of cell activities through calcium signaling as well as in posttranslational protein folding and maturation. Changes in calcium fluxes in ER are ultimately involved in this process. NCX is largely distributed close to the sarcoplasmic reticulum (SR)/endoplasmic reticulum (ER) $\mathrm{Ca}^{2+}$ stores in smooth muscle (Lederer et al. 1990; Moore et al. 1993) and astrocytes (Juhaszova et al. 1996). It was already shown that NCX1.7 overexpression increased apoptosis induced by ER $\mathrm{Ca}^{2+-}$ ATPase inhibitors cells (DiazHorta et al. 2002). NCX1.7 overexpression depleted ER Ca ${ }^{2+}$ stores, sensitized the cells to the calcium-independent proapoptotic signaling pathways, and reduced cell proliferation by approximately $40 \%$ cells (Diaz-Horta et al. 2002). In this work we have shown that induction of apoptosis by mixture of proapoptotic agents (using A) resulted in overexpression of the NCX1 in HeLa cell line without causing ER stress. Nevertheless, addition of $\beta 1$ and 2 -adrenergic agonist - isoproterenol - to the cells resulted in depletion of reticular calcium store and resulted in further increase in apoptosis. When individual components of A were used, increase in a number of apoptotic cells after I treatment compared to 
apoptosis only occurred with camptothecin. These results point to the proposal that potentiated apoptotic effect in isoproterenol-treated cells is due to the inhibition of nuclear topoisomerase. From these results it would be apparent that increase in NCX is associated with the increased apoptosis in cancer HeLa cells. However, there are some conflicting results published until now. Garcia-Prieto and coworkers (2012) described that natural product OSW-1, which exhibits a potent antitumour effect on leukemia cells, inhibited the sodium-calcium exchanger (NCX1) on the plasma membrane, leading to an increase in cytosolic $\mathrm{Ca}^{2+}$ and a decrease in cytosolic $\mathrm{Na}^{+}$. On the other side, overexpression of the NCX1 increases $\beta$-cell programmed cell death (apoptosis) and reduces $\beta$-cell proliferation (Nguidjoe et al. 2011). Also, NCX1.7 overexpression increased apoptosis induced by ER $\mathrm{Ca}^{2+}$-ATPase inhibitors in cells (Diaz-Horta et al. 2002). One of the possible explanations of this discrepancy might be functional cell disunity, but also individual compounds used.

There is growing evidence that some cancer progression is closely associated with beta- adrenoreceptors. Nevertheless, modulation of adrenergic receptors in cancer causes conflicting results. Non-selective $\beta$-ARs agonist isoproterenol significantly increased cell proliferation via $\beta$-ARs in a dose-dependent manner, with concomitant activation of ERK/MAPK signal pathway in human pancreatic ductal adenocarcinomas cell line (Panc-1 cells). I increased expression level of phosphorylated ERK in Panc-1 cells. Furthermore, in vivo study showed that I enhanced xenograft tumor growth and this effect was suppressed by non-selective $\beta$ ARs antagonist ( $\beta$-blocker), propranolol treatment (Lin et al. 2012). In the rat glioma cell line noradrenaline and the beta-adrenoceptor agonist isoproterenol showed significant inhibition of the 1,2,5(OH)2D3-induced programmed cell death. The $\beta$-adrenoceptor antagonist propanolol reversed this inhibition, while the alpha-adrenoceptor antagonist yohimbin was devoid of any effect. This suggests that the efficiency of antiproliferative vitamin D-related therapies could be influenced by endogenous levels of noradrenaline (Canova et al. 1997). On the other hand, Mamani-Matsuda and co-workers (Mamani-Matsuda et al. 2004) reported that $\beta 2$-adrenergic agents promote apoptotic leukemia cell death through $\mathrm{Ca}^{2+}$-dependent mechanism. Furthermore, it was shown that cell death of thymocytes can be induced after stimulation of $\beta$-adrenergic receptor, or by addition of exogenous cAMP. Apoptotic cell death in both cases was observed with the appearance of terminal deoxynucleotidyl transferase-mediated UTP-end labeling reactivity and the activation of caspase- 3 in S49 T cells (Gu et al. 2000). Also, $\beta$ AR activation induces apoptosis in immature $\mathrm{T}$ lymphocytes via $\mathrm{G}(\mathrm{s}) \alpha$ and PKA (Yan et al. 2000).

Our results support the pro-activatory effect of I on the apoptosis induction, however, mechanism is untill now not known. Based on the experiments with individual apoptotic inducers, especially camptothecin, we might propose that potentiated apoptotic effect in I-treated cells is due to the inhibition of nuclear topoisomerase. Nevertheless, this proposal remained to be verified. Differences of I effect might account for different types of cells used in the experiment and also different pro-apoptotic compounds.

Acknowledgements. This publication is result of Grants APVV 51-0045-11, VEGA 2/0095/13 and Center of excellence for studying metabolic aspects of development, diagnostics and treatment of the oncologic diseases (CEMAN). Project implementation: KC: ITMS 26240220071, supported by the Research \& Development Operational Programme funded by the ERDF.

\section{References}

Barman P., Choisy S. C. M., Hancox J. C., James A. F. (2011): Adrenoceptor/PKA-stimulation, $\mathrm{Na}+\mathrm{Ca} 2+$ exchange and PKA-activated Cl-currents in rabbit cardiomyocytes: A conundrum. Cell Calcium 49, 233-239

http://dx.doi.org/10.1016/j.ceca.2011.02.006

Basset O., Boittin F. X., Cognard C., Constantin B., Ruegg U. T. (2006): Bcl-2 overexpression prevents calcium overload and subsequent apoptosis in dystrophic myotubes. Biochem. J. 395, 267-276

http://dx.doi.org/10.1042/BJ20051265

Caba O., Rodríguez-Serrano F., Díaz-Gavilán M., Conejo-García A., Ortiz R., Martínez-Amat A., Alvarez P., Gallo M. A., Campos J. M., Marchal J. A., Aránega A. (2012): The selective cytotoxic activity in breast cancer cells by an anthranilic alcohol-derived acyclic 5-fluorouracil O,N-acetate is mediated by endoplasmic reticulum stress-induced apoptosis. Eur. J. Med. 50, 376-382 http://dx.doi.org/10.1016/j.ejmech.2012.02.017

Canova C., Baudet C., Chevalier G., Brachet P., Wion D. (1997): Noradrenaline inhibits the programmed cell death induced by 1,25-dihydroxyvitamin D3 in glioma. Eur. J. Pharmacol. 319, 365-368 http://dx.doi.org/10.1016/S0014-2999(96)00942-9

Danial N. N. (2007): BCL-2 family proteins: critical checkpoints of apoptotic cell death. Clin. Cancer. Res. 137, 254-7263

Diaz-Horta O., Kamagate A., Herchuelz A., Van Eylen F. (2002): $\mathrm{Na}+/ \mathrm{Ca} 2+$ exchanger overexpression induces endoplasmic reticulum-related apoptosis and caspase- 12 activation in insulin-releasing BRIN-BD11 cells. Diabetes 511, 815-1824

Eigel B. N., Gursahani H., Hadley R. V. (2004): Na+/Ca2+ exchanger plays a key role in inducing apoptosis after hypoxia in cultured guinea pig ventricular myocytes. Am. J. Physiol. Heart Circ. Physiol. 287, H1466-1475

http://dx.doi.org/10.1152/ajpheart.00874.2003

Entschladen F., Drell T. L. 4th, Lang K., Joseph J., Zaenker K. S. (2005): Neurotransmitters and chemokines regulate tumor cell migration: Potential for a new pharmacological approach to inhibit invasion and metastasis development. Curr. Pharm. Des. 11, 403-411 http://dx.doi.org/10.2174/1381612053382197 
Fendri A., Kontos CH. K., Khabir A., Mokdad-Gargouri R., Scorilas A. (2011): BCL2L12 is a novel biomarker for the prediction of short-term relapse in nasopharyngeal carcinoma. Mol. Med. 17, $163-171$ http://dx.doi.org/10.2119/molmed.2010.00056

Garcia-Prieto C., Riaz Ahmed K. B., Chen Z., Zhou Y., Hammoudi N., Kang Y., Lou C., Mei Y., Jin Z., Huang P. (2012): Effective killing of leukemia cells by the natural product osw-1 through disruption of cellular calcium homeostasis. J. Biol. Chem. 288, $3240-3250$

http://dx.doi.org/10.1074/jbc.M112.384776

Gu C., Ma Y. C., Benjamin J., Littman D., Chao M. V., Huang X. Y. (2000): Apoptotic signaling through the beta- adrenergic receptor, A new Gs effector pathway. J. Biol. Chem. 275, 20726-20733 http://dx.doi.org/10.1074/jbc.M000152200

Hanahan D., Weinberg R. A. (2000): The hallmarks of cancer. Cell $100,57-70$ http://dx.doi.org/10.1016/S0092-8674(00)81683-9

Herchuelz A., Diaz-Horta O., van Eylen F. (2002): Na/Ca exchange and $\mathrm{Ca} 2+$ homeostasis in the pancreatic beta-cell. Diabetes Metab. 28, S54-60

Hudecova S., Kubovcakova L., Kvetnansky R., Kopacek J., Pastorekova S., Novakova M., Knezl V., Tarabova B., Lacinova L., Sulova Z., Breier A., Jurkovicova D., Krizanova O. (2007): Modulation of expression of $\mathrm{Na}+/ \mathrm{Ca} 2+$ exchanger in heart of rat and mouse under stress. Acta Physiol. (Oxf) 190, 127-136 http://dx.doi.org/10.1111/j.1748-1716.2007.01673.x

Hudecova S., Lencesova L., Csaderova L., Sirova M., Cholujova D., Cagala M., Kopacek J., Dobrota D., Pastorekova S., Krizanova O. (2011): Chemically mimicked hypoxia modulates gene expression and protein levels of the sodium calcium exchanger in HEK 293 cell line via HIF-1a. Gen. Physiol. Biophys. 30, 196-206 http://dx.doi.org/10.4149//gpb_2011_02_196

Chiu S. C., Chen S. P., Huang S. Y., Wang M. J., Lin S. Z., Harn H. J., Pang C. Y. (2012): Induction of apoptosis, coupled to endoplasmic reticulum stress in human prostate cancer cells by n-butylidenephthalide. PLoS One 7, e33742 http://dx.doi.org/10.1371/journal.pone.0033742

Iwai-Kanai E., Hasegawa K., Araki M., Kakita T., Morimoto T., Sasayama S. (1999): $\alpha$ - and $\beta$-adrenergic Pathways differentially regulate cell type-specific apoptosis in rat cardiac myocytes. Circulation 100, 305-311 http://dx.doi.org/10.1161/01.CIR.100.3.305

Jakubikova J., Bao Y., Sedlak J. (2005): Isothiocyanates induce cell cycle arrest, apoptosis and mitochondrial potential depolarization in HL/60 and multidrug - resistant cell lines. Anticancer Res. 25, 3375-3386

Juhaszova M., Shimizu H., Borin M. L., Yip R. K., Santiago E. M., Lindenmayer G. E., Blaustein M. P. (1996): Localization of the $\mathrm{Na}+-\mathrm{Ca} 2+$ exchanger in vascular smooth muscle, and in neurons and astrocytes. Ann. N Y Acad. Sci. 779, 318-335 http://dx.doi.org/10.1111/j.1749-6632.1996.tb44804.x

Lederer W. J., Berlin J. R., Cohen N. M., Hadley R. W., Bers D. M., Cannell M.B. (1990): Excitation-contraction coupling in heart cells. Roles of the sodium-calcium exchange, the calcium current, and the sarcoplasmic reticulum. Ann. N. Y. Acad. Sci. 588, 190-206 http://dx.doi.org/10.1111/j.1749-6632.1990.tb13210.x

Lin X., Luo K., Lv Z., Huang J. (2012): Beta-adrenoceptor action on pancreatic cancer cell proliferation and Tumor growth in mice. Hepatogastroenterology 59, 584-588

Liu K. C., Yen C.Y., Wu R. S., Yang J. S., Lu H. F., Lu K. W., Lo C., Chen H. Y., Tang N. Y., Wu C. C., Chung J. G. (2012): The roles of endoplasmic reticulum stress and mitochondrial apoptotic signaling pathway in quercetin-mediated cell death of human prostate cancer PC-3 cells. Environ. Toxicol. (in press) http://dx.doi.org/10.1002/tox.21769

Lowry O. H., Rosebrough N. J., Farr A. L., Randall R. J. (1951): Protein measurement with the Folin phenol reagent. J. Biol. Chem. 193, 265-275

Maier L. S. (2012): New treatment options for late Na current, arrhythmias, and diastolic dysfunction. Curr Heart Fail Rep. 9, 183-191 http://dx.doi.org/10.1007/s11897-012-0099-3

Mamani-Matsuda M., Moynet D., Molimard M., Ferry-Dumazet H., Marit G., Reiffers J., Mossalayi M. D. (2004): Long-acting beta2-adrenergic formoterol and salmeterol induce the apoptosis of B-chronic lymphocytic leukaemia cells. Br. J. Haematol. 124, 141-150 http://dx.doi.org/10.1046/j.1365-2141.200

Mani S. K., Egan E. A., Addy B. K., Grimm M., Kasiganesan H., Thiyagarajan T., Renaud L., Heller Brown J., Kern C. H. B., Donald R., Menick D. R. (2010): $\beta$-adrenergic receptor stimulated NCX1 upregulation is mediated via a CaMKII/AP-1 signaling pathway in adult cardiomyocytes. J. Mol. Cell. Cardiol. 48, $342-351$ http://dx.doi.org/10.1016/j.yjmcc.2009.11.007

Miyamoto S., Howes A. L., Adams J. W. 2nd, Dorn G. W., Brown J. H. (2005): Ca2+ dysregulation induces mitochondrial depolarization and apoptosis: role of $\mathrm{Na}+/ \mathrm{Ca} 2+$ exchanger and AKT. J. Biol. Chem. 280, 38505-38512

http://dx.doi.org/10.1074/jbc.M505223200

Moore E. D., Etter E. F., Philipson K. D., Carrington W. A., Fogarty K. E., Lifshitz L. M., Fay F. S. (1993) Coupling of the Na+/Ca2+ exchanger, $\mathrm{Na}+/ \mathrm{K}+$ pump and sarcoplasmic reticulum in smooth muscle. Nature 365, 657-660 http://dx.doi.org/10.1038/365657a0

Oakes S.A., Lin S. S., Bassik M. C. (2006): The control of endoplasmic reticulum-initiated apoptosis by the BCL-2 family of proteins. Curr. Mol. Med. 6, 99-109 http://dx.doi.org/10.2174/156652406775574587

Orchard C., Brette F. (2008): t-Tubules and sarcoplasmic reticulum function in cardiac ventricular myocytes. Cardiovasc Res. 77, $237-244$ http://dx.doi.org/10.1093/cvr/cvm002

Pacak K., Sirova M., Giubellino A., Lencesova L., Csaderova L., Laukova M., Hudecova S., Krizanova O. (2012): NF-kB inhibition significantly upregulates the norepinephrine transporter system, causes apoptosis in pheochromocytoma cell lines and prevents metastasis in an animal model. Int. J. Canc. 131, 2445-2455 http://dx.doi.org/10.1002/ijc.27524

Papageorgiou S. G., Kontos CH. K., Pappa V., Thomadaki H., Kontsioti F., Dervenoulas J., Papageorgiou E., Economopoulos T., Scorillas A. (2011): The novel member of the BCL2 gene 
family, BCL2L12, is substantially elevated in chronic lymphocytic leukemia patients, supporting its value as a significant biomarker. The Oncologist 161, 1280-1291 http://dx.doi.org/10.1634/theoncologist.2010-0349

Park I. J., Kim M. J., Park O. J., Choe W., Kang I., Kim S. S., Ha J. (2012): Cryptotanshinone induces ER stress-mediated apoptosis in HepG2 and MCF7 cells. Apoptosis 17, 248-257 http://dx.doi.org/10.1007/s10495-011-0680-3

Roberts-Thomson S. J., Curry M. C. (2010): Monteith G.R. Plasma membrane calcium pumps and their emerging roles. World J. Biol. Chem. 1, 248-253 http://dx.doi.org/10.4331/wjbc.v1.i8.248

Rodriguez D., Rojas-Rivera D., Hetz C. (2011): Integrating stress signals at the endoplasmic reticulum: The BCL-2 protein family rheostat. Biochim. Biophys. Acta 181, 3564-574

Singh K., Xiao L., Remondino A., Sawyer D. B., Colucci W. S. (2011): Adrenergic regulation of cardiac myocyte apoptosis. J. Cell. Physiol. 89, 257-265

Teijido O., Dejean L. (2010): Upregulation of Bcl2 inhibits apoptosis-driven BAX insertion but favors BAX relocalization in mitochondria. FEBS Letters 584, 3305-3310 http://dx.doi.org/10.1016/j.febslet.2010.07.002
Zha L., Fan L., Sun G., Wang H., Ma T., Zhong F., Wei W. (2012): Melatonin sensitizes human hepatoma cells to endoplasmic reticulum stress-induced apoptosis. J. Pineal. Res. 52, 322-331 http://dx.doi.org/10.1111/j.1600-079X.2011.00946.x

Zhang D., Ma Q. Y., Hu H. T. and Zhang M. (2010): $\beta 2$-adrenergic antagonists suppress pancreatic cancer cell invasion by inhibiting CREB, NFKB and AP-1. Cancer Biol. Ther. 10, 19-29 http://dx.doi.org/10.4161/cbt.10.1.11944

Wang J. Y., Chen B. K., Wang Y. S., Tsai Y. T., Chen W. Ch., Chang W. Ch., Hou M. F., Wu W. Ch., Chang W. Ch. (2011): Involvement of store-operated calcium signaling in EGF-mediated COX-2 gene activation in cancer cells. Cell. Signal. 24, 162-169 http://dx.doi.org/10.1016/j.cellsig.2011.08.017

Yan L., Herrmann V., Hofer J. K., Insel P. A. (2000): beta-adrenergic receptor/cAMP-mediated signaling and apoptosis of S49 lymphoma cells. Am. J. Physiol. Cell Physiol. 279, C1665-1674

Youle R. J., Strasser A. (2008): The BCL-2 protein family: opposing activities that mediate cell death. Nat. Rev.Mol. Cell. Biol. 9, 47-59 http://dx.doi.org/10.1038/nrm2308

Received: March 20, 2013

Final version accepted: May 24, 2013 